\title{
THE PATHOGENIC EFFECTS OF MYCOBACTERIUM HAEMOPHILUM IN IMMUNOSUPPRESSED ALBINO MICE
}

\author{
M. R. Aвbott and D. D. Smith \\ Microbiology Department, The Prince of Wales Hospital, Randwick, NSW, Australia
}

\section{Plate XXXVI}

IN 1978, Sompolinsky and his colleagues reported the isolation of a previously unrecognised atypical mycobacterium from a granulomatous skin lesion of an immunosuppressed patient. These workers found that haemin was a required factor for growth of this organism in vitro and therefore proposed that the organism be named Mycobacterium haemophilum. In common with the two other atypical mycobacteria that are capable of causing skin lesions, $M$. ulcerans and $M$. marinum, this organism has an optimum growth temperature lower than that of $M$. tuberculosis and in fact grows poorly, if at all, at $35^{\circ} \mathrm{C}$.

Before the recognition of $M$. haemophilum, five cases of skin infection apparently caused by a mycobacterium were observed in immunosuppressed patients in one Sydney hospital (Mezo et al., 1979). The organism failed to grow on Löwenstein-Jensen or other media commonly used for the isolation of mycobacteria. However, from three of the five patients a mycobacterium was isolated on Löwenstein-Jensen medium supplemented with ferric ammonium citrate. A similar organism was isolated from the skin of an immunosuppressed patient in another Sydney hospital (Walder et al., 1976). Dawson and Jennis (1980) consider that all four isolates are identical with $M$. haemophilum.

This paper describes the pathogenic effects of $M$. haemophilum in prednisolone-treated mice infected experimentally and compares the main features of the naturally occurring disease in man with the artificial disease produced in mice.

\section{MATERIALS AND METHODS}

\section{Culture media}

Löwenstein-Jensen (LJ) medium was prepared by the method of Holm and Lester (1942); ferric ammonium citrate was added to give a final concentration of $2 \%(w / v)$ to produce ferric ammonium citrate Lowenstein-Jensen medium (FAC-LJ). At the time of this study it was not known that haemin is a growth requirement of $M$. haemophilum.

Nutrient blood agar for the detection and isolation of Corynebacterium murium and other rapidly growing pathogenic bacteria was prepared with Tryptone Soya Agar (Oxoid) containing horse blood $8 \%(\mathrm{v} / \mathrm{v})$.

Hoyle's tellurite agar (Cruickshank, 1965) was used for the isolation of C. murium. 


\section{Mycobacterium haemophilum}

The strain used in this study was isolated from an immunosuppressed patient (Walder $e t$ al., 1976). Subsequently, it was found to be identical in its growth requirement for haemin and other cultural characteristics with the strain of $M$. haemophilum described by Sompolinsky et al., (1978).

\section{Identification of corynebacteria}

The identification of the corynebacteria isolated from skin lesions was based on their microscopic, cultural and biochemical characteristics by reference to the appropriate tables of Cowan (1974).

\section{Determination of the effect of $M$. haemophilum infection on prednisolone-treated mice}

Four groups of 3-month-old female mice of the albino Prince Henry strain weighing 25-30 g, were used.

Group 1. Sixty mice were given prednisolone (Protea Pharmaceuticals Pty Ltd) dissolved in their drinking water at a dose of $1 \mathrm{mg} / \mathrm{kg}$ per day, calculated on the basis of a mouse body weight of $27.5 \mathrm{~g}$ and an observed average daily water consumption of $10 \mathrm{ml}$. Prednisolone administration was continued throughout the 5 -month test period.

Group 2. Thirty mice were given prednisolone as described above and were given one intravenous dose of $0.5 \mathrm{ml}$ of a saline suspension of $M$. haemophilum containing $2.4 \times 10^{8}$ colony-forming units $/ \mathrm{ml}$.

Group 3 . Thirty mice received the same dose of $M$. haemophilum as group 2 but were not given prednisolone.

Group 4. Sixty mice served as normal controls and were given neither prednisolone nor mycobacterial challenge.

The mice were observed daily throughout the study; at weekly intervals a record was made of their general condition, average body weight, development of skin lesions, total and differential white-cell counts and mortality rate. At the end of the 5-month test period, post-mortem studies were made on five of the surviving mice from each group. The method of Fenner, Martin and Pierce (1949) was used for the preparation of tissue homogenates, which were cultured on FAC-LJ medium. The presence and number per high-power field (h.p.f.) of mycobacteria in spleen, liver and lung tissue was determined by fluorescence microscopy, in which auramine is substituted for carbol fuchsin in the Ziehl-Neelsen method for detection of acid-fast bacilli (AFB) (Cruickshank, 1965).

\section{Bacteriological examination of skin lesions}

Swabs or tissue from skin lesions were homogenised in a Colworth Stomacher Model 80; smears were prepared and examined microscopically after staining by Gram's or the auramine fluorescent stain. The material was inoculated onto Hoyle's medium and nutrient blood agar as well as LJ and FAC-LJ media.

\section{RESULTS}

\section{The effects of prednisolone treatment on mice}

The following observations were made on the 60 mice in group 1 , which had not received mycobacterial challenge.

White blood-cell count. The total white-cell count from the peripheral blood of normal control mice, that is, those not receiving steroids, ranged from 
$8.0 \times 10^{3}$ to $13.6 \times 10^{3} / \mu 1$ with an average mononuclear count of $9.6 \times 10^{3} / \mu 1$ throughout the period of observation (table). In the prednisolone-treated group the total count fell to $4 \cdot 5-5 \times 10^{3} / \mu$ within 2 weeks of the beginning of treatment and remained at this level for the 5 months of the study. The leucopenia was accounted for by a reduction in the mononuclear cells with an average cell count in five animals of $2 \cdot 0 \times 10^{3} / \mu \mathrm{l}$ (table).

Corynebacterium murium skin lesions. In 10 of 60 mice given prednisolone, skin lesions over the nose and various parts of the head were observed after 10 weeks. These were abscesses which contained yellow pus and yielded a heavy growth of $C$. murium. Each lesion was 1-2 mm in diameter and was surrounded by a dull-red inflamed area over which there was a loss of hair. No such lesions were observed in mice not given prednisolone.

General conditions and mortality. The prednisolone-treated mice remained well for 6 weeks. Thereafter about half of the animals became lethargic and the coat became ruffled but there was no loss of weight. After 3 months, 10 of the 60 mice had died and after 5 months there were only 32 survivors (table). By contrast, all the mice not given prednisolone remained well throughout the whole experiment and none died.

Necropsy. The animals examined were those that died or were killed because of their poor condition and five of the survivors from each of the four groups at the end of the 5-month period of the study. The mean spleen weight in prednisolone-treated mice was only $57 \mathrm{mg}$ compared with $143 \mathrm{mg}$ in the control group (table). No other macroscopic changes were observed.

\section{The effects of $M$. haemophilum in prednisolone-treated and untreated mice}

Distinctive skin lesions containing AFB were observed on the ears of 12 of the 30 prednisolone-treated mice challenged with $M$. haemophilum (group 2), but no such lesions were observed in mice not given prednisolone in group 3 (table). These lesions were first observed c. 2 months after the commencement of the experiment (fig. 1). Smears prepared from homogenates of ear tissue obtained at necropsy were found to contain 20 or more AFB/h.p.f. (fig. 2).

TABLE

Results, at 5 months, of intravenous inoculation of M. haemophilum $\left(2.4 \times 10^{8}\right.$ c.f.u. $)$ into normal mice and mice given prednisolone (1 $\mathrm{mg} / \mathrm{kg}$ per day)

\begin{tabular}{|c|c|c|c|c|c|c|}
\hline $\begin{array}{l}\text { Group no., treatment } \\
\text { (and number of } \\
\text { mice in group) }\end{array}$ & $\begin{array}{l}\text { Mononuclear } \\
\text { cell count* } \\
\left(10^{3} / \mathrm{ml}^{*}\right)\end{array}$ & $\begin{array}{l}\text { Number of mice } \\
\text { with } C \text {. murium } \\
\text { skin lesions }\end{array}$ & $\begin{array}{l}\text { Number } \\
\text { of mice } \\
\text { that died }\end{array}$ & $\begin{array}{l}\text { Spleen } \\
\text { weight } \\
(\mathrm{mg})^{*}\end{array}$ & $\begin{array}{l}\text { Number of } \\
\text { AFB/h.p.f. } \\
\text { in splenic } \\
\text { smearst }\end{array}$ & $\begin{array}{l}\text { Number of mice } \\
\text { with } M \text {. haemophilum } \\
\text { skin lesions }\end{array}$ \\
\hline $\begin{array}{l}\text { 1. Prednisolone }(60) \\
\text { 2. Prednisolone; }\end{array}$ & 2.0 & 10 & 32 & 57 & 0 & 0 \\
\hline $\begin{array}{l}\text { M. haemophilum }(30) \\
\text { 3. M. haemophilum }(30) \\
\text { 4. None }(60)\end{array}$ & $\begin{array}{r}2 \cdot 9 \\
10 \cdot 8 \\
9 \cdot 6\end{array}$ & $\begin{array}{l}0 \\
0 \\
0\end{array}$ & $\begin{array}{l}6 \\
0 \\
0\end{array}$ & $\begin{array}{r}66 \\
250 \\
143\end{array}$ & $\begin{array}{c}20-25 \\
20-25 \\
0\end{array}$ & $\begin{array}{r}12 \\
0 \\
0\end{array}$ \\
\hline
\end{tabular}

AFB $/$ h.p.f. = acid-fast bacilli/high-power field.

* Average of five mice.

+ Average of three mice. 
Aggregates of mycobacteria similar to the globi of $M$. leprae found in lepromatous tissue were seen (figs. 2 and 3). Cultures from the ear lesions in the mice yielded a growth of mycobacteria on FAC-LJ medium but not on the LJ medium unsupplemented with ferric ammonium citrate.

In two of these 12 mice with mycobacterial lesions on the ears, similar lesions appeared on the dorsum of the foot 12 weeks after challenge. No such lesions attributable to AFB were detected in any of the other groups of mice.

White blood-cell count. The mononuclear count in prednisolone-treated mice challenged with $M$. haemophilum was reduced to a degree similar to that observed in unchallenged prednisolone-treated animals (table). In mice inoculated with $M$. haemophilum and which were not given prednisolone, the count remained the same as that of the normal controls (table).

C. murium skin lesions. The C. murium lesions seen in some of the group-1 mice were not observed in any of the prednisolone-treated mice challenged with $M$. haemophilum.

General condition and mortality. Of the animals given prednisolone, those infected with $M$. haemophilum remained healthier and had a better survival rate than the uninoculated animals. After 5 months, only 6 of 30 mice from the former group had died whereas, as reported above, 32 of 60 mice riven prednisolone but not infected with the mycobacterium had died. The ditierence was statistically significant $\left(\chi^{2}=8 \cdot 6\right)$. In normal mice not given prednisolone but infected with the mycobacterium there were no deaths.

Necropsy. The average spleen weight of five mice that did not eive prednisolone and were inoculated with $M$. haemophilum was $250 \mathrm{mg}$, compared with an average of $143 \mathrm{mg}$ in uninfected controls, which were not given prednisolone. The spleen of prednisolone-treated mice infected with $M$. haemophilum weighed $66 \mathrm{mg}$, a reduction similar to that observed in uninfected prednisolone-treated mice. Tubercles or other macroscopic changes were not apparent in the viscera of any of the animals examined.

Microscopic preparations of spleen homogenates of mice killed 5 months after inoculation with the mycobacterium were found to contain 20-25 $\mathrm{AFB} / \mathrm{h}$.p.f. AFB were also detected in liver and lung homogenates of both groups but were fewer than those found in the spleen. Culture of each of these viscera yielded growths of mycobacteria on FAC-LJ medium, but there was no growth on LJ medium not supplemented with the salt. The number of organisms was the same in prednisolone-treated and untreated animals.

\section{Discussion}

The salient finding of this study was the occurrence of skin lesions caused by $M$. haemophilum only in mice that were given prednisolone, just as human infection appears to be confined to patients who are immunosuppressed. Normal mice challenged with large doses of $M$. haemophilum intravenously did not develop skin lesions but did develop a low-grade, non-fatal, "Yersin" type of infection characterised by the absence of macroscopic tubercules and by enlargement of the spleen. 

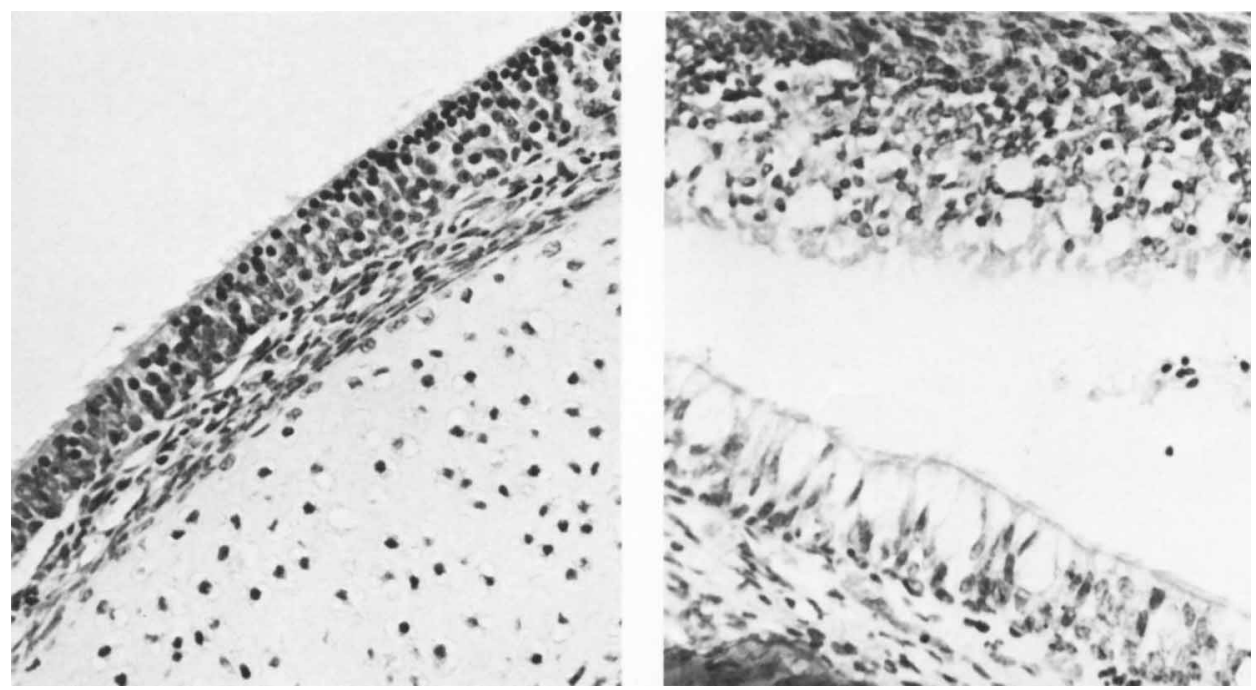

FIG. 1.-Ear lesions in a prednisolone-treated mouse challenged with $M$. haemophilum. Smears from the lesions contained acid-fast bacilli which grew on the appropriately modified Löwenstein-Jensen dium.

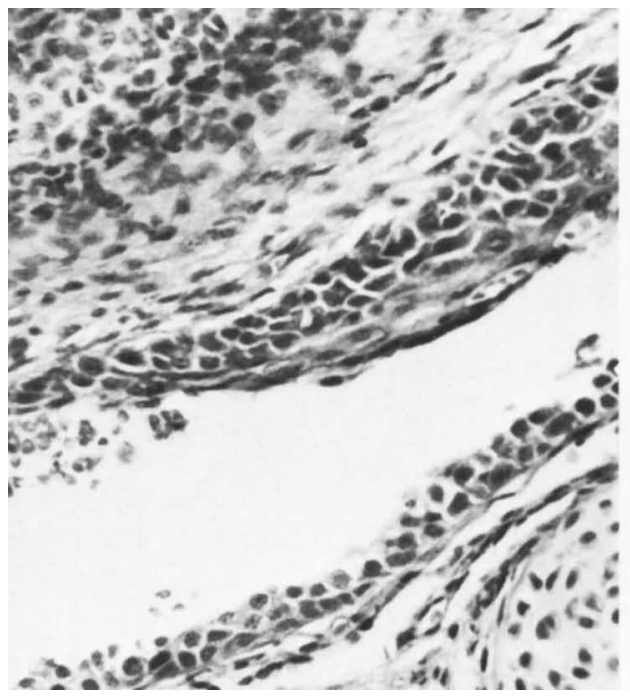

FIG. 2.-Acid-fast bacilli in an auraminestained smear from a homegenate of aural tissue from a prednisolone-treated mouse challenged 5 months previously with an inoculum $\left(2.4 \times 10^{8}\right.$ viable units $)$ of $M$. haemophilum.

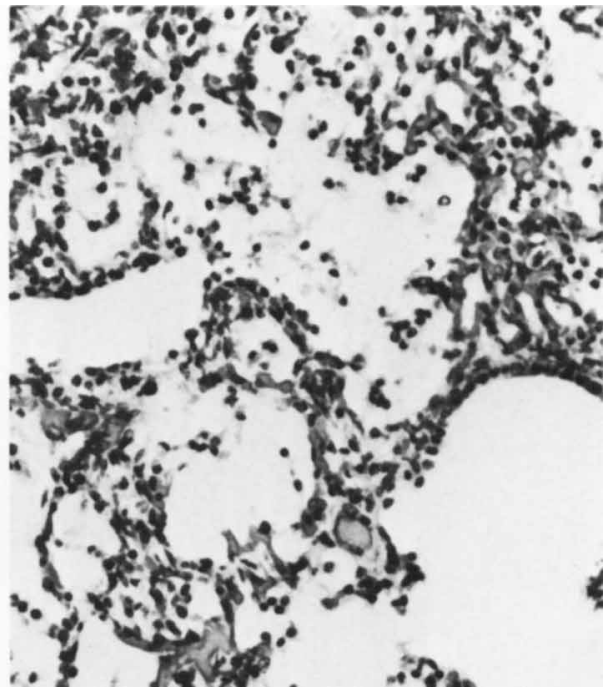

FIG. 3.-Acid-fast bacilli in an auramine stained smear from skin lesions in a patient with acute lepromatous leprosy. 
The dermotropism of this organism is characteristic of several other species of mycobacteria, namely, $M$. leprae, $M$. marinum and $M$. ulcerans. These cause infections that are restricted mainly to the cooler surface areas of the body of affected humans or animals (MacCallum et al., 1948; Shepard, 1965; Shepard and Habas, 1967). In keeping with this, as noted by Sompolinsky et al. (1978), the optimum temperature for growth of M. marinum, M. ulcerans and $M$. haemophilum is $30-32^{\circ} \mathrm{C}$, close to that of cutaneous tissue. $M$. haemophilum also bears some resemblance to $M$. leprae in that both species may appear in globus-like aggregations in mouse tissue. There are other similarities in the pathogenic effects of these two mycobacteria in mice. Rees (1965) observed macroscopic lepromatoid lesions in the ears and nose of mice challenged intravenously with $M$. leprae and rendered immuno-incompetent by thymectomy and irradiation. In steroid-treated mice, $M$. leprae was observed to multiply in the footpads of inoculated animals (Shepard and McCrae, 1965).

The deleterious effects on the condition of mice and other animals caused by prolonged steroid administration, observed in the present study, are well recognised. These include marked lymphopenia (Claman, 1972), splenic atrophy (Quittner et al., 1951), a high mortality rate (Tonelli, 1966) and the development of spontaneous infections including those caused by $C$. murium (Pierce-Chase, Fauve and Dubos, 1964). However, an unexpected finding in the present work was that $M$. haemophilum infection in prednisolone-treated mice was associated with a significant increase in the survival rate of these animals and fewer intercurrent infections compared with prednisolone-treated mice that were not infected with the mycobacterium. BCG infection has been observed to confer a similar protection against the pathogenic effects of a wide range of micro-organisms (Mackaness, 1964; Hobby and Lenert, 1971; Sher $e t$ al., 1975; Tabbara, O'Connor and Nozik, 1975). Therefore, the non-specific protection observed in this study may be similar to that attributed to BCG.

\section{SUMMARY}

Of 30 prednisolone-treated mice challenged intravenously with Mycobacterium haemophilum, 12 developed skin lesions, primarily on the ears, from which the mycobacterium was isolated. These lesions were not observed in mice challenged with $M$. haemophilum but not given prednisolone.

$M$. haemophilum infection prolonged the life and reduced the frequency of intercurrent infection with Corynebacterium murium in prednisolone-treated mice.

We acknowledge the helpful suggestions and criticisms made by our colleague Dr S. M. Bell during the course of this work, and the Department of Medical Illustration, University of New South Wales for the photographs.

\section{REFERENCES}

Claman, H. N. 1972. Corticosteroids and lymphoid cells. New Engl. J. Med., 287, 388.

Cowan, S. T. 1974. Cowan and Steele's Manual for the identification of medical bacteria. Cambridge University Press: Cambridge, p. 59. 
Cruickshank, R. 1965. Medical microbiology, 11th ed., Churchill Livingstone: Edinburgh, pp. 632 and 749.

Dawson, D. J. AND Jennis, F. 1980. Mycobacterium with a growth requirement for ferric ammonium citrate identified as Mycobacterium haemophilum. J. clin. Microbiol., 11, 90.

Fenner, F., Martin, S. P. AND PierCe, C. H. 1949. The enumeration of viable tubercle bacilli in cultures and infected tissues. Ann. N.Y. Acad. Sci., 52, 751.

HobBy, G.L. AND LeNerT, T. F. 1971. Cross immunity between mycobacterial and Pseudomonas pseudomallei infections in mice. Am. Rev. resp. Dis., 103, 569.

Holm, J. AND LeSTER, V. 1942. Diagnostic demonstration of tubercle bacilli. Acta tuberc. scand., 16, 310.

MacCallum, P., Tolhurst, J. C., Buckle, G. and Sissons, H. A. 1948. A new mycobacterial infection in man. J. Path. Bact., 60, 93.

MaCKANESS, G. B. 1964. The immunological basis of acquired cellular resistance. J. exp. Med., $120,105$.

Mezo, A., Jennis, F., MCCarthy, S. W. and Dawson, D. J. 1979. Unusual mycobacteria in 5 cases of opportunistic infection. Pathology, 11, 377.

Pierce-Chase, C. H., Fauve, R. M. and Dubos, R. 1964. Corynebacterial pseudotuberculosis in mice. I. Comparative susceptibility of mouse strains to experimental infection with Corynebacterium kutscheri. J. exp. Med., 120, 267.

QuitTNer, H., Wald, N., Sussman, L. N. AND ANTOPOL, W. 1951. The effect of massive doses of cortisone on the peripheral blood and bone marrow of the mouse. Blood, 6, 513 .

REES, R. J. W. 1965. Recent bacteriologic, immunologic and pathologic studies on experimental human leprosy in the mouse foot pad. Int. J. Lepr., 33, 646.

SHEPARD, C. C. 1965. Temperature optimum of Mycobacterium leprae in mice. J. Bact., 90, 1271 .

ShEPARD, C. C. AND Habas, J. A. 1967. Relation of infection to tissue temperature in mice infected with Mycobacterium marinum and Mycobacterium leprae. J. Bact., 93, 790.

ShePARD, C. C. AND MCCRAE, D. H. 1965. Mycobacterium leprae in mice: minimal infectious dose, relationship between staining quality and infectivity and effect of cortisone. J. Bact., 89, 365.

Sher, N. A., Chaparas, S. D., Greenberg, L. E. and Bernard, S. 1975. Effects of BCG, Corynebacterium parvum and methanol-extraction residue in the reduction of mortality from Staphylococcus aureus and Candida albicans infections in immunosuppressed mice. Infect. Immun., 12, 1325.

Sompolinsky, D., LAgZiel, A., NAveh, D. AND YANKIlevitz, T. 1978. Mycobacterium haemophilum sp. nov., a new pathogen of humans. Int. J. syst. Bact., 28, 67.

TabBara, K. F., O'Connor, G. R. AND Nozik, R. A. 1975. Effect of immunization with attenuated Mycobacterium bovis on experimental toxoplasmic retinochoroiditis. Am.J. Ophthal., 79, 641.

Tonelli, G. 1966. Acute toxicity of corticoids in the mouse. Steroids, 8, 857 .

Walder, B. K., Jeremy, D., Charlesworth, J. A., Macdonald, G. J., Pussell, B. A. and Robertson, M. R. 1976. The skin and immunosuppression. Aust. J. Derm., 17, 94. 